\title{
P31 - Natural history of wheat allergy in Greek children
}

\author{
Stavroula Giavi, Paraskevi Korovessi', Nikolaos Douladiris, Emmanouil Manousakis, Nikolaos G Papadopoulos \\ From 3rd Pediatric Allergy and Asthma Meeting (PAAM) \\ Athens, Greece. 17-19 October 2013
}

\section{Background}

Wheat allergy is one of the most common food allergies in children, yet few data are available regarding its natural history.

\section{Objectives}

To define the natural course of wheat allergy in Greek children and identify factors that may predict outcome.

\section{Methods}

We completed a retrospective medical record review of patients from the Allergy Clinic, 2nd Pediatric Clinic, University of Athens that were diagnosed as having wheat allergy. Patients were included in the study if they had a history of symptomatic reaction to wheat and or a positive wheat IgE test result.

Clinical history, laboratory results, and final outcome were recorded for 70 patients. Resolution of wheat allergy was based on food challenge results. Total IgE, wheat IgE (f4), specific gluten IgE (f79) and the ratio $\mathrm{f} 4 / \operatorname{lgE}$, (at presentation), were compared between children with active or resolved wheat allergy, 4 years after their first reaction, performing the non-parametric Mann-Whitney test.

\section{Results}

Rates of resolution were $20 \%$ by 5 years, $35 \%$ by 10 years (determined by Kaplan-Meier survival curves). Higher total IgE, f4, f79 or $\mathrm{f} 4 / \mathrm{IgE}$ levels (at presentation) were not strongly associated with poorer outcomes at 4 years. $\mathrm{f79}(p=0.095)$ and $\mathrm{f} 4(\mathrm{p}=0.063)$ slightly correlated with active allergy.

Median age of first reaction to wheat was 8 months. History of AD was present at $96 \%$ of all children. Children with still active wheat allergy accounted for the $72 \%$ of the

Allergy Clinic, $2^{\text {nd }}$ Pediatric Clinic, University of Athens, Athens, Greece population and $75 \%$ of them had no history of other food allergy. In contrast, all children with resolved wheat allergy had multiple food allergies.

\section{Conclusion}

The mean age of resolution of wheat allergy is approximately 11 years in this population $(95 \% \mathrm{CI}: 9,6-12,3)$. In a significant percentage of patients, wheat allergy persists into adolescence. Many children outgrew wheat allergy with even the highest levels of specific wheat IgE. Monosensitization to wheat appears to be a risk factor for persistence.

Published: 28 February 2014

\section{doi:10.1186/2045-7022-4-S1-P86}

Cite this article as: Giavi et al:: P31 - Natural history of wheat allergy in Greek children. Clinical and Translational Allergy 2014 4(Suppl 1):P86.
Submit your next manuscript to BioMed Central and take full advantage of:

- Convenient online submission

- Thorough peer review

- No space constraints or color figure charges

- Immediate publication on acceptance

- Inclusion in PubMed, CAS, Scopus and Google Scholar

- Research which is freely available for redistribution 